\title{
PEMODELAN RUAS JALAN TUNGGAL DENGAN DIAGRAM FUNDAMENTAL TRIANGULAR EQUILIBRIUM
}

\section{MODELING OF EQUILIBRIUM TRIANGULAR FUNDAMENTAL DIAGRAM ON A SINGLE ROAD LINK}

\author{
Mulyadi Sinung Harjono, Djoko Prijo Utomo \\ Pusat Teknologi Sistem dan PrasaranaTransportasi \\ Kedeputian Teknologi Industri Rancang Bangun dan Rekayasa - BPPT \\ Gedung Teknologi 2 BPPT Lantai 3, Kawasan PUSPIPTEK, Tangerang Selatan 15314 \\ Telp: 021-75875938; Fax. 021-75875946 \\ e-mail: mulyadi.sinung@bppt.go.id, djoko.prijo@bppt.go.id
}

\begin{abstract}
Abstrak
Paper ini berisi tentang model ruas jalan tunggal untuk kondisi lalu lintas kendaraan makroskopik pada ruas jalan tunggal berdasarkan diagramfundamental-triangular-equilibrium (DFTe) dengan hybrid - Petri nets. Integrasi DFTe ke dalam model HPN dilakukan dengan memodelkan 1) infrastruktur ruas jalan menggunakan struktur dinamis jaringan HPN, 2) dinamika jumlah kendaraan pada titik keluar ruas jalan saat steady-state dengan parameter kecepatan firing internal $\lambda$. Kondisi lalu lintas kendaraan pada ruas jalan tunggal ditunjukkan oleh evolusi aliran arus dan evolusi token saat steady-state. DFTe diperoleh dari kumpulan berbagai kondisi lalu lintas kendaraan steady-state pada ruas jalan tertentu. Non-linearitas DFTe dimodelkan dengan sinkronisasi transition HPN menggunakan minimum-operator. Penelitian ini menghasilkan pemodelan baru DFTe menggunakan timed HPN dengan infinite-serversemantics untuk diterapkan pada ruas jalan tunggal. Pemodelan baru DFTe untuk ruas jalan tunggal terbukti lebih baik, karena dapat menunjukkan kondisi lalu lintas arus bebas, arus stabil dan arus tertahan.
\end{abstract}

Kata kunci : triangular fundamental diagram; model ruas jalan tunggal, hybrid petri nets.

\begin{abstract}
This paper focuses on hybrid-Petri-net (HPN) modeling for macroscopic vehicle traffic flow on single-road-links and road-networks based on the equilibrium-triangular-fundamental-diagram (DFTe). The integration of DFTe into the HPN models is performed by 1) modeling road-link infrastructures using dynamic-structure of HPN, 2) determining the steady-state number of vehicles at the road link output using internal firing speed $\lambda$. Vehicle traffic condition for a single-road-link is shown by vehicle-traffic-flow evolution and token evolution at steady-state. The DFTe is obtained by computing various steady-state vehicle traffic condition on a single-road-link. Non-linearity modeling of DFTe is performed by sinchronization of a HPN transitions using minimumoperator. This paper has contribution, i.e. enhanced DFTe modeling using timed HPN under infinite-server-semantics for single-road-links and road-networks. The enhanced DFTe modeling for single-road-links has been proven to perform better in the free-flow, saturated and synchronized state of vehicle traffic.
\end{abstract}

Key Words : triangular fundamental diagram; single road link models; hybrid petri nets

Diterima (received ) : 22 Maret 2019 , Direvisi (revised ) : 05 April 2019,

Disetujui (accepted) : 15 Mei 2019 


\section{PENDAHULUAN}

Sistem transportasi cerdas (Intelligent Transportation System - ITS) adalah suatu sistem yang dibentuk dengan segala upaya dan secara sinergis memanfaatkan teknologi dan konsep rekayasa sistem bidang teknik elektro dan teknologi informasi untuk mengembangkan dan meningkatkan kinerja sistem transportasi, baik dari aspek teoritis, eksperimental, dan operasional ${ }^{1}$. Penerapan ITS mencakup perencanaan, rekayasa teknik dan manajemen operasi pengendalian lalu lintas. Analisis lalu lintas untuk penerapan ITS dapat dilakukan melalui pemodelan dan simulasi secara mikroskopik, mesoskopik dan makroskopik ${ }^{2}$. Pada paper ini, kondisi lalu lintas suatu ruas jalan dimodelkan secara makroskopik dengan melakukan diskretisasi-ruang jalan. Hasil diskretisasi ini membentuk suatu model yang tersusun atas banyak ruas jalan tunggal. Setiap model untuk satu ruas jalan tunggal memiliki karakteristik makroskopik yang sama. Karakteristik makroskopik model untuk satu ruas jalan tunggal ditunjukkan oleh 3 (tiga) parameter makroskopik yang saling terkait, yaitu kepadatan kendaraan (density), aliran arus kendaraan (throughput,traffic-flow) dan kecepatan ratarata banyak kendaraan.

Keterkaitan spesifik antar parameter makroskopik pada satu ruas jalan terjadi pada kondisi steady state dan kondisi equilibrium. Kondisi steady state terjadi ketika terdapat kondisi lalu lintas tertentu yang menyebabkan masing-masing parameter makroskopik tersebut mencapai nilai stabil. Kondisi equilibrium adalah kumpulan segala kemungkinan kondisi steady state untuk satu ruas jalan tertentu yang dipetakan pada diagram antar parameter makroskopik dan disebut sebagai diagram fundamental lalu lintas (fundamental traffic diagram). Pada diagram fundamental (lalu lintas) equilibrium tersebut diperoleh penggolongan kondisi lalu lintas dan tingkat pelayanan jalan, yaitu kondisi arus bebas (free-flow state), arus stabil (saturated state), arus tertahan (synchronized state) maupunmacet total (jammed). Ukuran kinerja diagram fundamental equilibrium pada paperini berdasarkan hubungan antara parameter aliran arus kendaraan terhadap kepadatan kendaraan. Konsep diagram fundamental (equilibrium) ini diperkenalkan oleh Lighthill, Whitham,dan Richards disebut sebagaimodel-LWR. Pendekatan modelLWR ini disederhanakan secara matematis menjadi diagram fundamental triangular(DFT $)^{3}$. Pemodelan untuk jalan yang panjang memerlukan diskretisasi-ruang jalan menjadi potongan banyak ruas jalan tunggalsesuai DFT. Gabungan model ruas jalan tunggal menjadi model jaringan jalan dibuktikan secara matematis dengan finite element ${ }^{3}$ dan dengan stochastic hybrid model ${ }^{4)}$.

Dalam paper ini dilakukan pemodelan sistem DFT dengan hybrid Petri net (HPN) untuk ruas jalan tunggal dan jaringan jalan. HPN adalah suatu metode formal untuk pemodelan kejadian diskrit dan kontinyu dengan kemampuan grafis untuk menyusun pemodelan modular, dan dengan kemampuan formulasi matematis aljabar dalam bentuk matriks. Pemodelan modular adalah metode penguraian suatu proses ke dalam model sesuai konsep simpul struktur jaringan Petri net. Struktur Petri net ini merupakan bipartite graph yang tersusun atas dua jenis simpul, yaitu place dan transition. Kedua simpul dapat terhubung hanya oleh satu anak panahsearah. Perubahan nilai "state" pada HPN ditunjukkan oleh jumlah token (marking) dalam place,dan digunakan untuk menunjukkan dinamika model sistem. Formulasi matematis proses perubahan nilai "state" pada HPN terdapat pada transition. Formulasi matematis pada transition mencakup proses aktifasi (enabling), pelepasan token (firing), evolusi token pada place, dan evolusi aliran arus pada transition.

Pemodelan sistem dengan Petri net disebut pemodelan hybrid, apabila memenuhi karakteristik 1). pemodelan sistem kejadian diskrit dengan analisa dan simulasi menggunakan komponen transition Petri net diskrit dan kontinyu secara bersamaan dalam satu model ${ }^{3)}$, ataupun 2). pemodelan sistem kejadian diskrit bersifat piecewise-linier dengan menggunakan sinkronisasi pada komponen transition Petri net kontinyu ${ }^{5}$.

Penelitian ITS mutakhir untuk pemodelan diagram fundamental pada ruas jalan denganHPN telah dilakukan oleh Júlvez dan Boè( $\left.{ }^{6}\right)$ dan Fanti et al. ${ }^{7}$.Júlvez dan Boèl(6) telah mengusulkan dua konsep, yaitu:

1) Pemodelan mendekati DFT equilibriumpada ruas jalan tunggal dengan ketergantungan pada dua peubah (variable) untuk kondisi lalu lintas arus bebas, dan

2) Pemodelan diagram fundamental equilibriumpada jaringan jalan hanya untuk kondisi lalu lintas arus tertahan saja.

Penelitian pemodelan diagram fundamental equilibrium oleh Fanti et al. ${ }^{7)}$ pada ruas jalan tunggal dan jaringan jalan 
bebas hambatan menggunakan first-order hybrid Petri net (FOHPN), dimana terdapat data parameter makroskopik riil pembentuk diagram fundamental, dan skenario simulasi untuk evaluasi kinerja jaringan jalan.Berdasarkan penelitian pemodelan diagram fundamental mutakhir pada ruas jalan tunggal dan jaringan jalan ${ }^{6) 7}$, maka pada paper ini dilakukan pengembangan lebih lanjut pemodelan baru DFT equilibrium dengan HPN.

Tujuan penelitian ini adalah mengembangkan pemodelan baru DFT equilibriumuntuk ruas jalan tunggal menggunakan HPN dengan kemampuan memodelkan kondisi lalu lintas arus bebas, arus stabil dan arus tertahan. Pengembangan pemodelan baru ini diawali dengan analisis kebutuhan parameter model sistem. Analisis dilakukan dengan memisahkan parameter tetap (statis) untuk infrastruktur jalan dan parameter dinamis terkait aliran arus kendaraan. Hasil analisis parameter ini menjadi dasar dikembangkannya model baru HPN untuk DFT equilibrium untuk seluruh kondisi arus lalu lintas pada ruas jalan tunggal. Hasil analisis utama model sistem yang dikembangkan menunjukkan, bahwa kecepatan firing internal $\lambda$ pada pemodelan baru HPN menentukan dinamika jumlah (aliran arus) kendaraan pada titik keluar ruas jalan tunggal saat steady-state.

Analisa kinerja yang dilakukanterhadap hasil pemodelan baru HPN untuk DFT equilibrium pada ruas jalan tunggal adalah mencakup analisa struktural jaringan, analisa urutan kemungkinan firing (firing sequence) dan analisa matematis. Evaluasi kinerja lanjutanmenggunakan data penelitian riil Fanti et al.9) terhadappemodelan baru HPN tersebut adalah mencakup 1). evaluasi reachability nilai token untuk setiap place, dan 2). evaluasi kondisi lalu lintas arus bebas, arus stabil dan arus tertahan saatsteady-state untuk aliran token dan aliran arus transition. Akhirnya, berdasarkan simulasi model untuk berbagai kondisi lalu lintas saat steady-state tersebut diperoleh diagram fundamental triangular equilibrium pada ruas jalan tunggal tertentu tersebut.

Kemudahan yang diperoleh dari pemilihan penggunaan HPN untuk pemodelan ruas jalan tunggal dan jaringan-jalan adalah sebagai berikut.

1). Sifat modular model Petri nets menunjang konsep makroskopik untuk diskretisasi-ruang jalan, sehingga model jaringan jalan dapat terbentuk dari model gabungan banyak model ruas jalan tunggal.
2). Kemampuan dekomposisi simpul pemodelan Petri nets menunjang proses penguraian sifat non-linieritas pada model dengan konsep diagram fundamental triangular untuk kondisi lalu lintas arus bebas, arus stabil, dan arus tertahan.

3). Kemampuan simulasi evolusi aliran arus setiaptransition dan evolusi token setiap place berdasarkan waktu menunjang kemampuan analisa parameter pada kondisi steady state dan kondisi equilibrium.

Kontribusi pertama adalah pemodelanbaru HPN untuk diagram fundamental triangular equilibrium pada ruas jalan tunggal. Model baru ini terbukti mampu menunjukkan kondisi lalu lintas arus bebas, arus stabil dan arus tertahan. Dengan demikian, pemodelan baru HPN ini mampu mendekati realitas kondisi lalu lintas ruas jalan tunggal dengan lebih baik dibandingkan dengan model Júlvez dan Boèl' ${ }^{6}$ yang hanya mampu menunjukkan kondisi lalu lintas terbatas untuk kondisi lalu lintas arus tertahan saja.

\section{TINJAUAN TEORITIS}

Penerapan model-LWR untuk kondisi lalu lintas rata-rata memerlukan pembagian jaringan jalan $x$ menjadi potongan banyak ruas jalan tunggal (spatialdiscretization) dengan masing-masing dari titik lokasi jalan $x_{i}$ tertentu dan panjang ruas jalan $l_{i}$. Pada diskretisasi jaringan jalan ini berlaku $x=$ $\sum_{i=1}^{n} x_{i}$ dengan $n$ adalah jumlah diskretisasi. Setiap ruas jalan tunggal diasumsikan memiliki nilai parameter makroskopik yang sama dan homogen sepanjang potongan ruas jalan dan selama inkremen waktu dari saat $t$ sampai $\Delta t$.

Hukum kekekalan kendaraan pada ${ }^{5)}$ untuk jaringan jalan $x$ saat $t$ adalah $\frac{\partial \rho\left(x_{i} t\right)}{\partial t}+=0$.

Dengan $\rho(x, t)$ adalah kepadatan kendaraan jaringan jalan $x$ saat $t$, dan $q(x, t)$ adalah aliran arus lalu lintas pada jaringan jalan $x$ saat $t$. Apabila perilaku dinamika lalu lintas pada model-LWR dianalogikan menurut hukum hidrodinamika untuk arus pergerakan partikel atau gas ${ }^{3)}$, maka hubungan matematis antar parameter makroskopik untuk potongan ruas jalan $x_{i}$ saat $t$ adalah $q_{X_{i}}(t)=\rho_{X_{i}}(t) \cdot v_{X_{i}}(t)$, dengan $v_{X_{i}}$ adalah estimasi kecepatan rata-rata banyak kendaraan untuk ruas jalan $x_{i}$ selama inkremen $\Delta t$ dimulai saat $t$. 
Hasil pengukuran ketiga parameter makroskopik kondisi lalu lintas ratarataataupun estimasinya untuk ruas jalan $x_{i}$ saat $t$ diperoleh setelah kondisi stabil (steady state) tercapai, yaitu selama inkremen $\Delta t$ dimulai saat $t$. Pada kondisi steady state hasil pengukuran parameter makroskopik dianggap valid. Apabila parameter makroskopik untuk keseluruhan kondisi lalu lintas rata-rata saat steady state untuk ruas jalan $x_{i}$ dicatat dan dikumpulkan selama kurun waktu mencukupi sedemikian rupa, sehingga seluruh kemungkinan kondisi lalu lintas rata-rata dapat terwakili dengan baik, maka diperoleh catatan kondisi lalu lintas equilibrium ruas jalan $x_{i}$. Pada kondisi equilibrium ini diperoleh segala kemungkinan keterkaitan antar parameter makroskopik yang tidak tergantung fungsi waktu, namun merupakan fungsi dari potongan ruas jalan tunggal. Pemetaan seluruh hubungan antar parameter makroskopik membentuk diagram fundamental lalu lintas equilibrium untuk ruas jalan $x_{i}$ yang tidak tergantung dari fungsi waktu. Diagram fundamental equilibrium pada paper ini menunjuk pada hubungan antara parameter aliran arus lalu lintas terhadap kepadatan kendaraan.

Apabila kecepatan rata-rata banyak kendaraan yang diukur $v_{X_{i}}(t)$ dapat diestimasisama dengan nilai kecepatan ratarata yang diperoleh dari diagram fundamental equilibrium $V_{e}\left(\rho_{X_{i}} t\right)$ sebagaimana $v_{X_{i}}(t)=V_{e}\left(\rho_{X_{i}}, t\right)$, maka nilai aliran arus lalu lintas equilibrium dapat diestimasi pula melalui diagram fundamental equilibrium. Sebelum memperoleh nilai estimasi aliran arus lalu lintas, maka berlaku hukum kekekalan kendaraan pada diagram fundamental equilibrium untuk setiap potongan ruas jalan $x_{i}$, yaitu $\frac{\partial \rho_{x_{i}}(t)}{\partial t}+\stackrel{\partial}{-}=0$. Sehingga, nilai hasil estimasi aliran arus lalu lintas kendaraan equilibriumQ $Q_{e}$ berdasarkan diagram fundamental equilibrium adalah sesuai persamaan $Q_{e}\left(\rho_{X_{i}}, t\right)=\rho_{X_{i}}(t) \cdot V_{e}\left(\rho_{X_{i}} t\right)$.

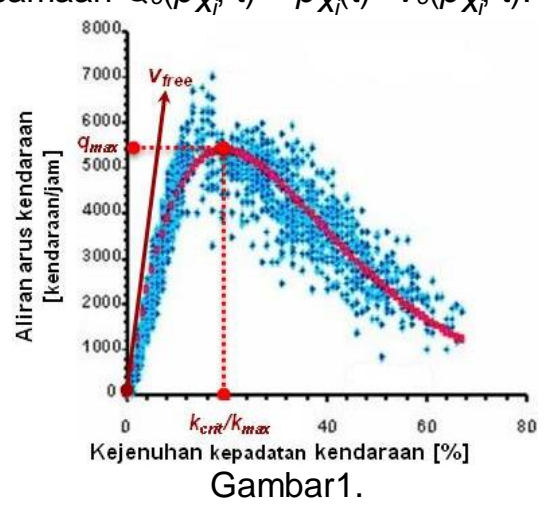

Diagram Fundamental Hidrodinamik ${ }^{8)}$
Diagram fundamental hidrodinamik ${ }^{8}$ sesuai Gambar 1 adalah diagram fundamental equilibrium untuk arus lalu lintas kendaraan $Q_{e, a}$ pada ruas jalan a terhadap kepadatan kendaraan $\rho$ dengan mengikuti prinsip hidrodinamik ${ }^{9}$. Pemanfaatan prinsip hidrodinamik ini mengandalkan pengambilan data kecepatan rata-rata banyak kendaraan untuk membentuk kecepatan rata-rata banyak kendaraan equilibrium-

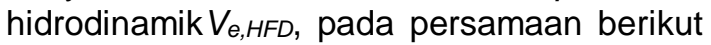
ini.

$$
\begin{aligned}
& V_{e, H F D}\left(\rho_{X_{a}}(K)\right)=V_{\text {free }} \cdot \exp \left[-\left(1 / a_{H F D}\right)\right. \\
& \cdot\left(K / K_{\text {crit }}\right)^{\left.a_{H F D}\right]}
\end{aligned}
$$

Pembentukan diagram fundametal equilibrium hidrodinamik untuk ruas jalan tunggal $x_{a}$ dengan asumsi $V_{e}\left(\rho_{X_{a}}, t\right)=$ $V_{e, H F D}\left(\rho_{X_{a}}(K), t\right)$ adalah pada persamaan berikut dan Gambar 1.

$Q_{e, a}(\rho(K), t)=$

$\rho(K,) \cdot v_{\text {free }} \exp$

$$
\left[-\frac{1}{a_{H F D}}\left(\frac{\rho\left(K_{\mathrm{i}}\right.}{\rho\left(K_{\mathrm{G}}\right.}(2)\right.\right.
$$

Setiap titik biru pada Gambar 1 diagram fundamental hidrodinamik ${ }^{8)}$ menunjukkan hasil pengukuran arus lalu lintas terhadap kepadatan kendaraanpada kondisi steady state. Setiap titik merah pada pada Gambar 1 memperlihatkan estimasi diagram fundamental hidrodinamik pada diagram aliran arus lalu lintas kendaraan $Q_{e, a}$ terhadap kejenuhan kepadatan kendaraan $\rho(K)$ dalam \%.Pada diagram fundamental hidrodinamik tersebut ditunjukkan aliran arus lalu lintas maksimum $q_{\max }$ saat kejenuhan kepadatan kendaraan kritikal dan kecepatan rata-rata banyak kendaraan pada kondisi arus bebas Vfree.

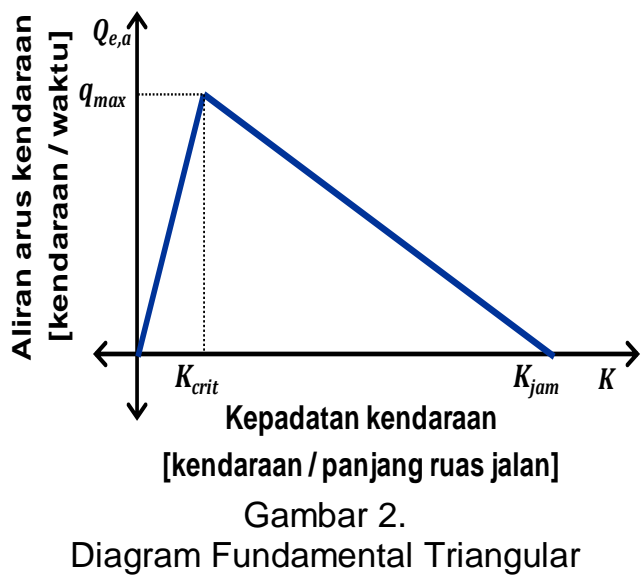

Tinjauan teori selanjutnya adalah mengenai diagram fundamental triangular $(D F T)^{3)}$ sesuai Gambar 2 yang merupakan 
penyederhanaan secara matematis diagram fundamental (equilibrium) untuk parameter aliran arus terhadap kepadatan kendaraan dan berbentuk segitiga. Pemanfaatan DFT mengandalkan perubahan jumlah kendaraan yang berpotensi masuk keruas jalan dibandingkan terhadap ketersediaan ruang pada ruas jalan. Persamaan potensi aliran arus kedatangan kendaraan equilibrium disebut diagram demand $\Delta_{e, a}(\rho(K))$.

$\Delta_{e, a}(\rho(K))=\quad\left\{\begin{array}{c}q_{e a}^{d}(\rho(K)) \text { untuk } \\ q_{\max \alpha^{w}} \text { untukk } K_{\text {crit }}<\end{array}\right.$

Persamaan untuk menunjukkan ketersediaan ruang sesuai kapasitas menerima arus lalu lintas kedatangan equilibrium disebut diagram supply $\Sigma_{e, a}(\rho(K))$ dan sesuai persamaan berikut ini.

$$
\Sigma_{e, a}(\rho(K))=\left\{\begin{array}{c}
q_{\max a^{w}} \text { untuk } K \leq K_{\mathrm{i}} \\
q_{e, a}^{g}(\rho(K)), \text { untuk } K_{\text {erit }}<K
\end{array}\right.
$$

Diagram fundamental triangular equilibrium dibentuk oleh persamaan aliran arus equilibrium $Q_{e, a}$ yang tersusun sebagai hasil interaksi antara diagram demand $\Delta_{e, a}$ dan diagram supply $\Sigma_{e, a}$ untuk ruas jalan tunggal a terhadap kepadatan kendaraan $\rho(K)$ pada persamaan berikut.

$$
Q_{e, a}(\rho(K))=\min \left[\Delta_{e, a}(\rho(K)), \Sigma_{e, a}(\rho(K))\right]
$$

Penyelesaian matematis untuk interaksi demand $\Delta_{e, a}$ dan supply $\Sigma_{e, a}$ menggunakan minimum-operator (min). Operator 'min' adalah suatu operasi matematika untuk memilih (sinkronisasi) output perhitungan dari salah satu suku persamaan pilihan dengan nilai hasil perhitungan aliran arus lalu lintas kendaraan yang paling kecil, yaitu dari suku persamaan demand $\Delta_{e, a}$ atau suku persamaan supply $\Sigma_{e, a}$.

Kondisi lalu lintas kendaraan pada DFT sesuai Gambar 2 memiliki 3 (tiga) fase. Fase pertama adalah kondisi lalu lintas arus bebas dan jumlah kendaraan antara $0<K<K_{\text {crit. }}$ Kecepatan rata-rata banyak kendaraan pada kondisi arus bebas disebut kecepatan freeflow $V_{\text {free. }}$ Fase kedua dinamakan kondisi lalu lintas arus tertahan dengan dengan jumlah kendaraan antara $K_{c r i t}<K<K_{j a m}$. Kecepatan rata-rata banyak kendaraan pada kondisi tertahan dinamakan kecepatan tertahan atau gelombang sinkron $V_{\text {wave. }}$ Fase ketiga adalah fase perpindahan kondisi lalu lintas arus bebas ke arus tertahan yang disebut kondisi arus stabil. Kondisi arus stabil ditandai oleh arus lalu lintas kendaraan maksimum $q_{\max , a}$ dan kepadatan kendaraan dengan jumlah kendaraan kritikal $K=K_{\text {crit. }}$

\section{METODE PENELITIAN}

Metode formal penelitian pemodelan pada paper ini menggunakanhybrid Petri net (HPN). Secara umum HPN terbagi atas untimed HPNdan timed $\mathrm{HPN}^{9)}$. Komponen utama penyusun struktur jaringan untimed HPN adalah $\mathbf{N}=\langle P, T$, Pre, Post $\rangle$. Simpul pada struktur jaringan HPN dapat dihubungkan dengan anak panah yang hanya memiliki satu arah. Dinamika struktur jaringan HPN diperoleh dari matriks insiden $\boldsymbol{C}=$ Post - Pre.

Model Petri nets yang hanya berdasarkan struktur jaringan $\mathbf{N}$ saja bersifat statis. Dinamika kondisi keadaan (state) dalam struktur jaringan model HPN ditunjukkan oleh dinamika token dengan formulasi matematis $\mathbf{N}=\left\langle\mathbf{N}, \boldsymbol{m}_{\mathbf{0}}\right\rangle$. Vektor matriks $\boldsymbol{m}$ adalah vektor matriks jumlah token pada setiap simpul placep $\in$ Pdengan nilai vektor matriks token dan token awal $\boldsymbol{m}, \boldsymbol{m}_{\boldsymbol{o}} \in \mathbb{R}_{\geq 0}|\boldsymbol{P}|$. Dinamika struktur jaringan HPN dihasilkan oleh firing. Setiap firing dipicu atau diaktifkan oleh kejadian tertentu. Akibat proses firing tersebut terjadi evolusi token pada place dan evolusi aliran arus pada transition.

Proses pemenuhan persyaratan batas nilai minimal (enabling degree) pada transition untuk dapat aktif disebut pengaktifan kejadian (event enabling) transition. Persamaan untuk menentukan nilai enabling degree (enab) transitiont ${ }^{10)}$.

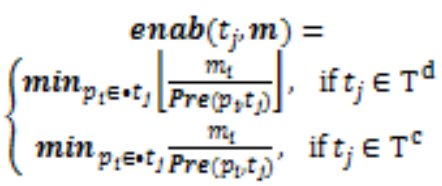

Firing pada transitiont menghasilkan evolusi token padaplace. Proses evolusi token dapat dibedakan menjadi 2 (dua), yaitu 1). evolusi token tunggal untuk setiap langkah kejadian firing dan 2). evolusi token gabungan untuk melihat hasil rangkaian firing dari nilai awal token hingga mencapai nilai token tertentu. Evolusi token tunggal pada fireabletransitiont; dengansatu langkah firing, menghasilkan vektor matriks token baru $\boldsymbol{m}$ 'yang berasal dari vektor matriks token awal $\boldsymbol{m}_{\boldsymbol{0}}$, sehingga berlaku $\boldsymbol{m}^{\prime}=\boldsymbol{m}_{\mathbf{0}}+\alpha$ - $\boldsymbol{C}\left(\bullet, \boldsymbol{t}_{j}\right)$ dengan nilai token $\boldsymbol{m}_{\mathbf{0}}, \boldsymbol{m}^{\prime} \geq 0$. Selanjutnya, evolusi token gabungan diturunkandari persamaan evolusi token tunggal dan disebut sebagai persamaan fundamental (fundamental state equation) ${ }^{6}$ ) dan berlaku $\boldsymbol{m}=\boldsymbol{m}_{\boldsymbol{0}}+\boldsymbol{C} \cdot \boldsymbol{\sigma}$. 
Struktur timed HPN sebagai jenis kedua HPN memiliki komponen utama, yaitu untimed HPN dengan memperhatikan fungsi waktu pada kecepatan firing internal $\lambda \in \mathbb{R}_{\geq 0}|T|$ untuk transition $T \in T^{D} \cup T^{C}$, sehingga berlaku $\mathbf{N}=\left\langle\mathbf{N}, \boldsymbol{m}_{0}, \boldsymbol{\lambda}\right\rangle$. Pada fireable transition $t$ dengant $\in \mathrm{T}^{\mathrm{D}}$ yang dikenal sebagai timed discrete firing berdasarkan waktu kejadian ${ }^{8)}$ terdapat deterministic delay-, immediate-dan probabilistic distributed delay firing. Timed HPN pada transition kontinyu dengan $t \in T^{C}$ berkaitan erat dengan proses evolusi token gabungan. Penyelesaian persamaan fundamental pada proses evolusi token gabungan sebagai fungsi waktu adalah $\boldsymbol{m}(\tau)=\boldsymbol{m}_{0+} \boldsymbol{C} \cdot \boldsymbol{\sigma}(\tau)$. Dengan $\boldsymbol{\sigma}(\tau)$ adalah vektor penghitung firing sebagai fungsi waktu pada interval $[0, T]$. Pada turunan pertama persamaan fundamental berdasarkan waktu berlaku $\dot{\boldsymbol{m}}=\boldsymbol{C}$. , dengan $\boldsymbol{f}=$ menunjukkan aliran arus (tokenthroughput, flow) untuk transition kontinyu $t_{i} \in T^{c}$. Dengan demikian, turunan pertama persamaan fundamental adalah $\dot{\boldsymbol{m}}=\boldsymbol{C} \cdot \boldsymbol{f}$.

Secara konseptual terdapat dua jenis timed firing transition kontinyu, yaitu 1).infinite server semantic (ISS firing), dan 2).finite server semantic (FSS firing). Persamaan aliran arus transition ISS firing pada transitiont $t_{i}$ sesuai $f_{i}=\lambda_{i} \cdot \min _{p_{j} \in \cdot t_{i}}\left(m_{j}\right)$ $\left.\operatorname{Pre}\left(p_{j}, t_{i}\right)\right)$. Persamaan aliran arus fipadatransition $t_{i}$ merupakan fungsi kecepatan firing internal $\lambda_{i}$ dan enabling degree. Faktor enabling degreeenab $(t, \boldsymbol{m})$ menunjukkan besaran server aktif yang terdapat pada transitionti saat token $\mathbf{m}$. Pemodelan aliran arus transition ini dapat mengandung persamaan non-linear dengan adanya penggunaan min-operator.

\section{HASIL PENELITIAN}

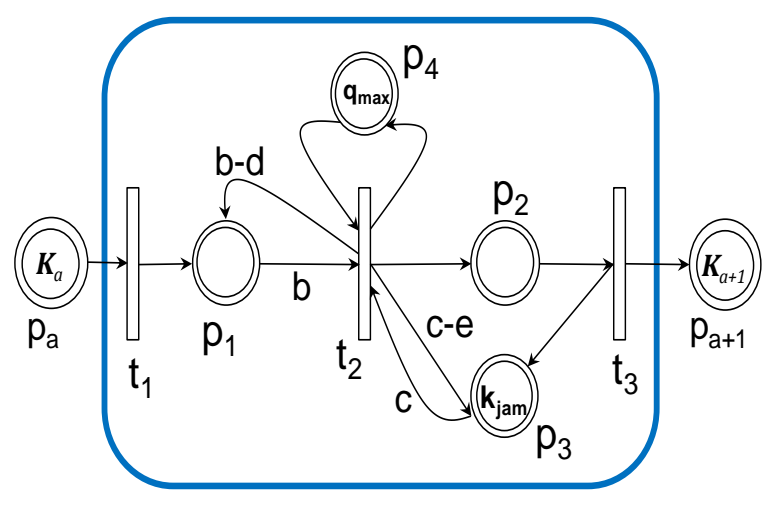

Gambar 3.

Model Diagram Fundamental Triangular Untuk Ruas Jalan Tunggal
Paper ini menunjukan pemodelan diagram fundamental triangular (DFT) yang bersifat makroskopik dengan hybrid Petri net sesuai Gambar 3 untuk ruas jalan tunggal dan tergantung pada parameter aliran arus lalulintas, kepadatan kendaraan dan kecepatan rata-rata banyak kendaraan. Pada pemodelan makroskopik, interaksi antar kendaraan bersifat mikroskopik diabaikan.

Kelas transition firing sesuai Gambar 3 adalah timed continuous transition dengan (ISS firing). Sehingga model paper ini dapat disebut secara khusus dikembangkan dengan timed hybrid Petri net dengan infinite server semantics firing (timed HPN-ISS). Struktur dinamis jaringan model initersusun atas komponen berikut ini.

a). 3 (tiga) timed continuous transition - ISS firing dengan $T=\left\{t_{1}, t_{2}, t_{3}\right\}$.

b). 6 (enam) place dengan $P=\left\{p_{1}, p_{2}, p_{3}, p_{4}\right.$, $\left.p_{a}, p_{a+1}\right\}$, token memiliki notasi $\boldsymbol{m}=\left\{m_{1}\right.$, $\left.m_{2}, m_{3}, m_{4}, m_{a}, m_{a+1}\right\}$ dengan nilai token awal adalah $\boldsymbol{m}_{0}=\left\{0,0, k_{j a m}, q_{\max }, m_{a, 0}\right.$, $m_{a+1,0\}}$.

c). Matriks pra insiden, $\operatorname{Pre}=\{0$ b $0 ; 001 ; 0$ c 0;0 10; $100 ; 000\}$

d). Matriks pasca insiden, Post $=\{1 b-d 0 ; 0$ $10 ; 0$ c-e 1;010;10 0;0 01$\}$

Timed continuous transition pada model sesuai Gambar 3 masing-masing memiliki fungsi, yaitu 1). $t_{1}$ sebagai input transition, 2). $t_{3}$ sebagai output transition dan 3). $t_{2}$ sebagai pembentuk aliran arus lalu lintas kendaraan non-linear sesuai DFT. Proses penyelesaian persamaan aliran arus non-linear ini disebut sinkronisasi anggota preset $t_{2}$. Proses sinkronisasi ini dilakukan secara matematis menggunakan min-operator. Keluaran dari transition $t_{2}$ membentuk token output aktual untuk ruas jalan tunggal pada $m_{2}$. Token output aktual ini mengaktifkan aliran arus lalu lintas pada output transition $t_{3}$. Token hasil aliran $t_{3}$ terakumulasi pada sink place $p_{a+1}$ dengan nilai token $m_{a+1}$.

Keenam place pembentuk model DFT adalah $\left\{p_{1}, p_{2}, p_{3}, p_{4}, p_{a}, p_{a+1}\right\}$. Nilai token awal dalam setiap place adalah menentukan perilaku model. Token awal $m_{1,0}=0$ memiliki arti, bahwa aliran arus lalu lintas pada DFT yang diperhitungkan dimulai dari nul. Token awal $m_{2,0}=0$ menunjukkan, bahwa kondisi awal jumlah kendaraan pada ruas jalan tersebut adalah kosong. Token awal $m_{3,0}$ adalah konstanta $k_{j a m \text {, yaitu jumlah }}$ kendaraan maksimal yang dapat mengisi ruas jalan tunggal pada kondisi macet total. Token awal $m_{4,0}$ adalah konstanta $q_{\max }$, yaitu aliran arus lalu lintas kendaraan maksimum 
yang dapat melalui ruas jalan tunggal. Token awal $m_{a, 0}$ harus lebih besar dari nul untuk dapat mengaktifkan input transitiont ${ }_{1}$ dan menunjukkan transition flow awal $q_{a, 0}$ yang dapat dicapai. Komponen matriks insiden Pre dan Post adalah matriks-bobot-anakpanah sebelum masuk proses dan setelah keluar proses pada masing-masing transition. Komposisi nilai komponen matriks insiden dapat dipergunakan untuk menentukan derajat kemiringan garis pada model diagram fundamental triangular.

Parameter kecepatan firing internal $\lambda$ pada setiap transition menentukan nilai akhir aliran arus transitiondan jumlah token saat steady state.Transitiont $t_{1}$ dan $t_{2}$ pada model ruas jalan tunggal ini adalah merupakan transition acuan bagi transition $t_{3}$ dengan kecepatan firing internal $\lambda t_{1}$ dan $\lambda t_{2}$ tetap dan bernilai 1 (satu). Parameter kecepatan firing internal $\lambda t_{3}$ pada output transition $t_{3}$ bertindak sebagai peubah untuk menentukan nilai aliran arus lalu lintas pada akhir ruas jalantunggal saat steady state sesuai diagram fundamental triangular.

Model baru diagram fundamental triangular ini merupakan perbaikan dan peningkatan model diagram fundamental Júlvez dan Boèl ${ }^{6}$. Model diagram fundamental triangular baru ini mampu 1).memisahkan ketergantungan antara struktur dinamis jaringan timed HPN-ISS (N, $m_{0}$ ) terhadap kecepatan firing internal $\lambda$, dan 2).model diagram fundamental triangular untuk ruas jalan tunggal ini dapat menunjukkan perilaku kendaraan rata-rata untuk kondisi arus tertahan, arus stabil dan arus bebas.

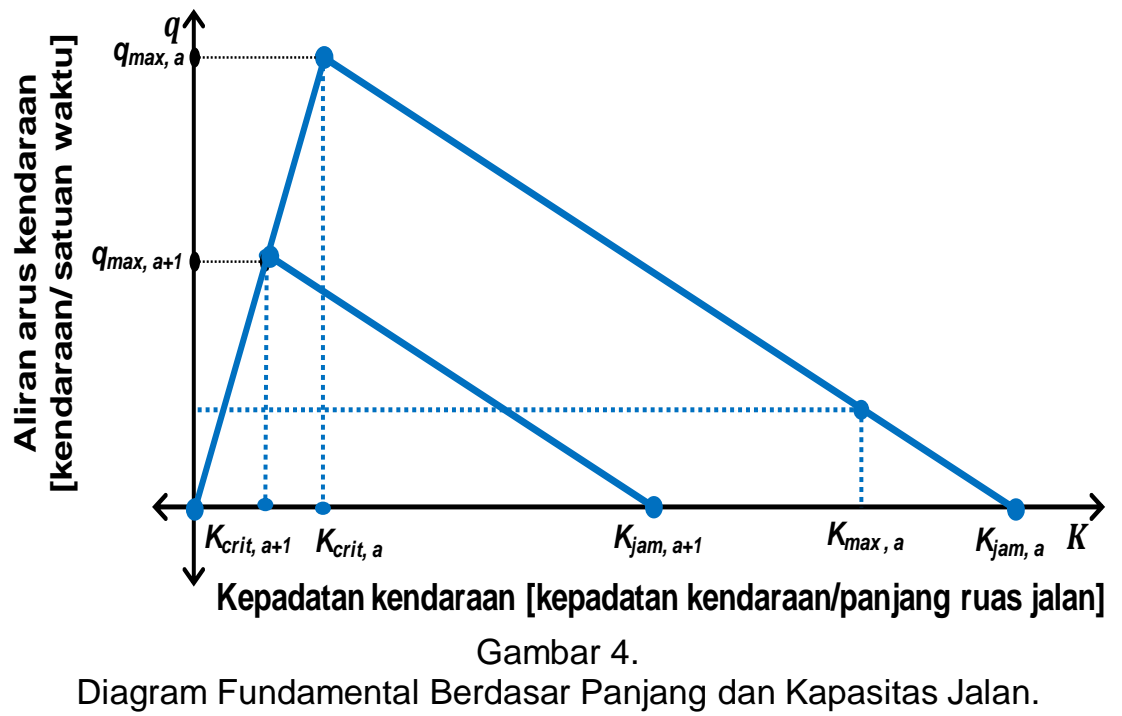

Parameter makroskopik penyusun $F D_{a}$ adalah aliran arus kendaraan maksimum $q_{\text {max,a, }}$ kepadatan kendaraan kritikal $K_{\text {crit,a, }}$ aliran arus kendaraan pada saat kepadatan kendaraan kritikal qKmax,a, kepadatan kendaraan kritikal $K_{\max , a}$, dan kapasitas ruas jalan saat macet $K_{j a m, a}$. Apabila ruas jalan tunggal a dengan $F D_{a}$ yang memiliki panjang ruas jalan $l_{a}$ digabung dengan ruas jalan $a+1$ dengan $F D_{a+1}$ yang memiliki panjang ruas jalan $l_{a+1}=\left(\beta \times l_{a}\right)$, maka kapasitas ruas jalan $a+1$ saat macet total adalah $K_{j a m, a+1}=(\beta$ $\left.\times K_{\text {jam,a }}\right)$. Jika $V_{\text {wave }}$ dan $V_{\text {free }} u n t u k$ ruas a dan $a+1$ adalah sama dan konstan, maka diperoleh $K_{\text {crit }, a+1}=\left(\beta \times K_{\text {crit,a }}\right)$ dan $q_{\max , a+1}=(\beta$ $\left.\times q_{\text {max }, a}\right)$. Dengan demikian, keseluruhan perbandingan parameter untuk diagram fundamental triangular untuk $F D_{a}$ dan $F D_{a+1}$ adalah sebagaimana Gambar 4.

\section{PEMBAHASAN}

Pembahasanini berkaitan dengan evaluasi kinerja hasil penelitian pemodelan baru dengan timed hybrid Petri net kelas infinite server semantics firing untuk diagram fundamental triangular pada ruas jalan tunggal dan jaringan jalan yang dikembangkan berdasar model diagram fundamental oleh Júlvez dan Boèl( ${ }^{6}$ dan diuji validitasnya dengan menggunakan skenario simulasi dan data lalu lintas jaringan jalan bebas hambatan dari model diagram fundamental hidrodinamik oleh Fanti et al. ${ }^{7}$. 


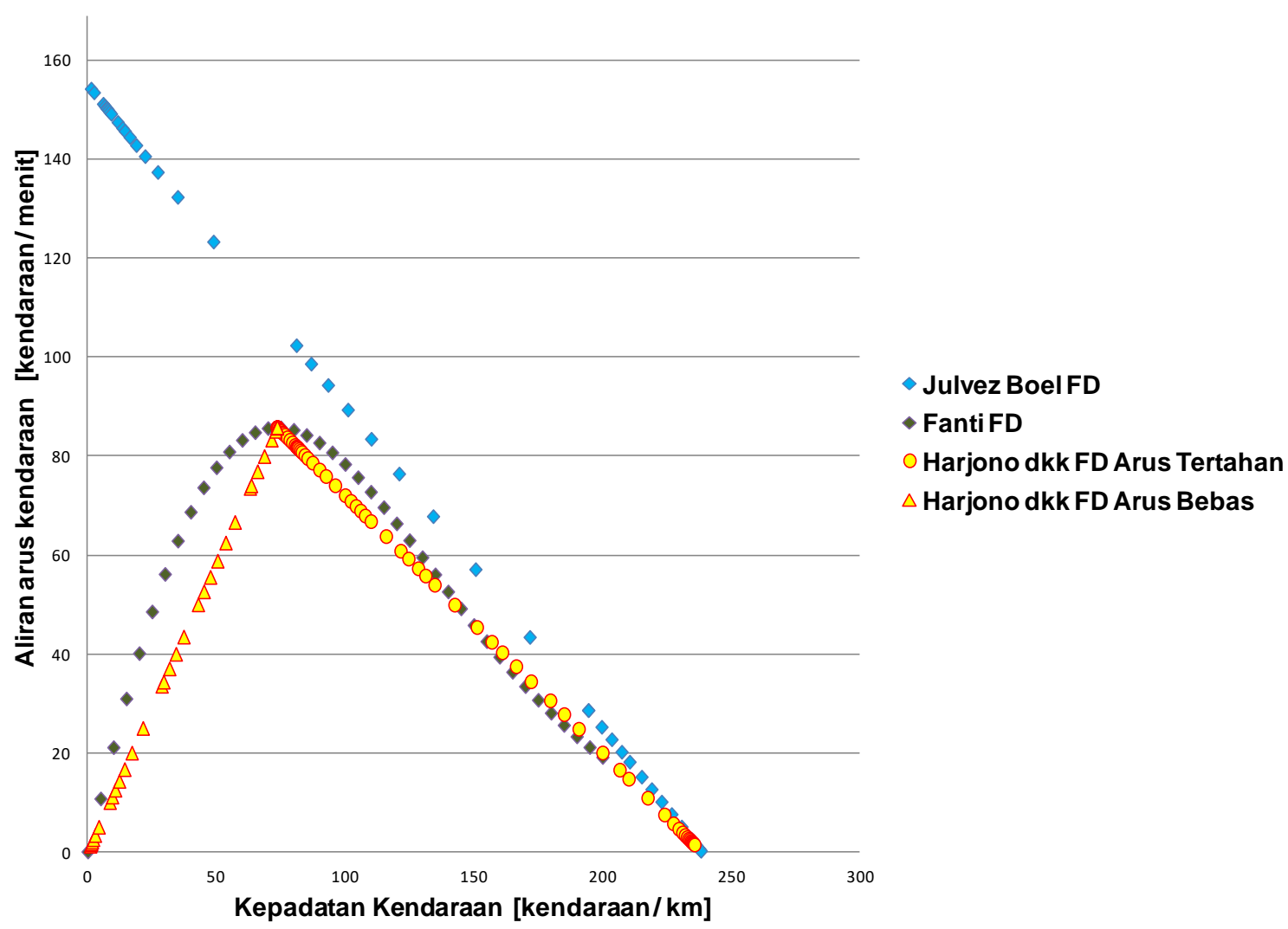

Gambar 5.

Perbandingan Model Diagram Fundamental

Pembahasan hasil penelitian pertama adalah mengenai diagram fundamental pada ruas jalan tunggal untuk aliran arus lalu lintas token terhadap jumlah token padamodel timed HPN-ISS yang telah dikembangkan oleh Júlvez dan Boè ${ }^{8)}$ atau disebut sebagai 'Julvez Boel FD'. Model diagram fundamental 'Julvez Boel FD' untuk aliran arus lalu lintas token pada transition $f t_{1}$ terhadap jumlah token pada kondisi 'arus bebas' secara matematis tergantung dua peubah, yaitu parameter kecepatan firing internal $\lambda t_{1}$ dan parameter bobot anak panah $q$ untuk matriks pasca-insiden $\operatorname{Post}\left(t_{1}, \quad p_{1}\right)$ dan matriks pra-insiden $\operatorname{Pre}\left(p_{1}, t_{1}\right)$. Namun, pada kondisi 'arus tertahan' model tersebut hanya bergantung pada parameter kecepatan firing internal $\lambda t_{1}$. Ketergantungan terhadap dua parameter peubah pada kondisi 'arus bebas' ini, menyebabkan model tersebut tidak dapat diterapkan secara praktis untuk mendekati kondisi 'arus bebas' pada diagram fundamental triangular.

Perbandingan hasil pengembangan pemodelan baru diagram fundamental triangular yang disebut sebagai 'Harjono $d k k$ $F D$ ' terhadap pemodelan diagram fundamental 'Julvez Boel FD' terdapat pada Gambar 5. Diagram fundamental 'Julvez Boel $F D$ ' dapat memperlihatkan dinamika kondisi 'arus tertahan' dengan baik, namun tidak dapat menunjukkan dinamika kondisi 'arus bebas'. Diagram fundamental triangular' Harjono dkk FD' telah dibuktikan dapat menunjukkan dinamika kondisi 'arus bebas' dan kondisi 'arus tertahan'. Diagram 'Harjono dkk $F D$ ' dianalisa validitasnya berdasarkan diagram fundamental hidrodinamik untuk jalan bebas hambatan dari Fanti et al. ${ }^{7}$ yang disebut sebagai 'Fanti $F D$ '. Diagram fundamental triangular berdasarkan 'Harjono dkk FD' sebagaimana pada 'Fanti $F D$ ' dapat memperlihatkan hasil yang lebih mendekati kondisi diagram fundamental sebenarnya dibandingkan diagram fundamental 'Julvez Boel FD'. Hasil simulasi model baru pada Gambar 3 dan analisa 'Harjono $d k k$ FD' memperlihatkan, bahwa evolusi aliran arus dan evolusi token saat steady state ditentukan dari nilai parameter $\lambda t_{3}$.

\section{SIMPULAN}

Paper ini memberikan kontribusi pemodelan baru diagram fundamental triangular dengan hybrid Petri nets pada ruas jalan tunggal dan jaringan jalan sebagai berikut. Satu model baru diagram fundamental triangular dengan hybrid Petri nets untuk ruas jalan tunggal berasal dari model diagram fundamental oleh Júlvez dan 
Boèl yang berlaku hanya untuk kondisi arus tertahan saja. Model ini telah dikembangkan menjadi model diagram fundamental triangular baru yang mampu menunjukkan kondisi arus bebas, arus stabil dan arus tertahan. Dengan demikian, pemodelan baru hybrid Petri nets ini mampu mendekati realitas kondisi aliran lalu lintas ruas jalan tunggal dengan lebih baik.

\section{UCAPAN TERIMA KASIH}

Ucapan terima kasih disampaikan kepada Kalamullah Ramli dan Abdul Halim yang telah memberikan fasilitas dan membantu untuk kelancaran penelitian ini.

\section{DAFTAR PUSTAKA}

1. IEEE Intelligent Transportation System Society website, diakses 10Desember 2018, http://sites.ieee.org/itss/about/.

2. M. Treiber dan A. Kesting, Verkehrsdynamik und-simulation: Daten, Modelle und Anwendungan der Verkehrsflussdynamik, Springer-Verlag, Berlin Heidelberg, 2010.

3. R. David dan H. Alla, Discrete, Continuous, and Hybrid Petri Nets,Springer-Verlag, Berlin Heidelberg, Revised 2nd edition, 2010.

4. H.Y. Sutarto, R.K. Boel, E. Joelianto, Parameter estimation for stochastic hybrid model applied to urban traffic flow estimation, IET Control Theory \& Applications, Vol. 9, Issue: 11, pp. 16831692,Jul. 2015.
5. M. Silva dan L. Recalde, Continuization of Timed Petri Nets: From Performance Evaluation to Observation and Control, Applications and Theory of Petri Nets, vol. 3536 of Lecture Notes in Computer Science, pp. 832-833, 2005.

6. J. Júlvez dan R. K. Boèl, A Continuous Petri Net Approach for Model Predictive Control of Traffic Systems, IEEE Trans. Syst., Man, Cybern. Part A, vol. 40, no. 4, pp. 686-697, Jul. 2010.

7. M. P. Fanti, G. lacobellis, A. M. Mangini dan W. Ukovich, Freeway Traffic Modeling and Control in a First-Order Hybrid Petri Net Framework, IEEE Trans. Autom. Sci. Eng., vol. 11, no. 1, pp. 90-102, Jan. 2014.

8. Lebacque, J.-P. dan Khoshyaran, M. , First-Order Macroscopic Traffic Flow Models: Intersection Modeling, Network Modeling In: Transportation and traffic theory, flow, dynamics and human interaction, $\mathrm{H}$. Mahmassani ed. Elsevier, pp.365-386, 2005

9. M. Silva, J. Júlvez, C. Mahulea, dan C.R. Vázquez, On fluidization of discrete event models: observation and control of continuous Petri nets, Discrete Event Dyn. Syst., vol. 21, pp. 427-497, Sep. 2011.

10. J. Júlvez, C. Mahulea, dan C.R. Vázquez,SimHPN: A MATLAB toolbox for simulation, analysis and design with hybrid Petri nets, Nonlinear Analysis: Hybrid Systems, vol. 6, pp. 806-817, May 2012. 
(halaman ini sengaja dikosongkan) 